\title{
Hypothyroidism Preceding Hyperthyroidism in a Patient with Continuously Positive Thyroid Stimulating Antibody
}

\author{
Hiromi Yamasaki, Kyoko Takeda, Yu NaKauchi, Tadashi Suehiro and Kozo Hashimoto
}

\begin{abstract}
A 62-year-old woman was initially hypothyroid and then developed hyperthyroidism with continuously positive thyroid-stimulating antibody (TSAb). When she visited our hospital with the complaint of the feel of skipping beats, her serum free $T_{4}$ level was initially low and thyrotropin (TSH) level was slightly elevated. One month after starting the supplement therapy with $\mathrm{l}_{\mathrm{T}} \mathrm{T}_{4}$, she developed hyperthyroidism with increased ${ }^{123}$ I-thyroid uptake. TSH-binding inhibitor immunoglobulin (TBII) was slightly elevated only during the hypothyroid stage. Throughout the whole course, TSAb was continuously positive, while thyroid stimulation-blocking antibody (TSBAb) was not detectable. Primary hypothyroidism with TSAb may suggest the possibility of subsequent development of hyperthyroidism.
\end{abstract}

(Internal Medicine 34: 247-250, 1995)

Key words: thyrotropin binding inhibitor immunoglobulin (TBII), thyroid-stimulation blocking antibody (TSBAb), TSH receptor antibody (TRAb), hypothyroidism, hyperthyroidism

\section{Introduction}

It is known that some patients with primary hypothyroidism develop hyperthyroidism. However, there have been few studies in which thyrotropin (TSH) receptor antibody (TRAb) was serially determined during the course of the illness from hypothyroidism to hyperthyroidism (1-8). The sequential change in TRAb was observed also in euthyroid subjects who subsequently developed hyperthyroidism due to Graves' disease (911). Here we report a case of mild primary hypothyroidism with moderately positive thyroid-stimulating antibody (TSAb) two months before the onset of Graves' hyperthyroidism.

\section{Methods}

TSH-binding inhibitor immunoglobulin (TBII), TSAb and thyroid-stimulation blocking antibody (TSBAb) were measured by the following methods. TBII was measured by a radioreceptor assay for TSH $(12)($ normal $<15 \%)$. TSAb was determined by a bioassay which measures cyclic adenosin monophosphate (cAMP) produced in cultured porcine thyroid cells as an index of stimulation according to the method developed by Amino et al (13) and Watanabe et al (14). Briefly, the thyroid cell suspension was incubated with crude IgG fractions sedimented by $15 \%$ polyethylene glycol in hypotonic medium. The amount of cAMP released during the 18-hour incubation was determined, and the potency of TSAb was expressed as an equivalent of bTSH [normal, $<0.3 \mu \mathrm{U} / \mathrm{ml}$ bovine TSH equivalent (bTSHeq.)]. In this assay system, bTSH at 1,10 and $100 \mu \mathrm{U} / \mathrm{ml}$ elicits a 3.6-, 14.6- and 43.0-fold increase in cAMP, respectively. To determine the activity of TSBAb, the thyroid suspension was incubated with the crude IgG fraction and bTSH (the final concentration, $100 \mu \mathrm{U} / \mathrm{ml}$ ) for 2 hours. The blocking activity was expressed as the percentage inhibition of cAMP increase, calculated as follows: [1-(cAMP generated in the presence of patient's IgG and TSH/cAMP generated in the presence of normal pooled $\operatorname{IgG}$ and TSH)] $\times$ $100 \%$ (normal $<20 \%$ ). Serum TSH at concentrations lower than $30 \mu \mathrm{U} / \mathrm{ml}$ does not cause false-positive or false-negative results from these TSAb and TSBAb measurements, respectively (15).

\section{Case Report}

A 62-year-old woman visited to our hospital in August 1992 due to the feeling of skipping beats and general fatigue. She had a decreased pulse rate, a small goiter without any tenderness, and no exophthalmos. Her goiter had been pointed out in June 1992 at a general clinic but she had been given no medicine. She had had no iodine overintake. Serum free $\mathrm{T}_{4}$, total $\mathrm{T}_{3}$ and TSH levels were $0.46 \mathrm{ng} / \mathrm{dl}, 102 \mathrm{ng} / \mathrm{dl}, 19.6 \mu \mathrm{U} / \mathrm{ml}$, respectively.

From the Second Department of Internal Medicine, Kochi Medical School, Nankoku Received for publication May 18, 1994; Accepted for publication October 26, 1994

Reprint requests should be addressed to Dr. Kyoko Takeda, Clinical Laboratory Medicine, Kochi Medical School, Kohasu, Oko-cho, Nankoku 783 
One month after treatment with $1-\mathrm{T}_{4}(50 \mu \mathrm{g} /$ day $)$, she developed tachycardia and moist skin. Serum free $\mathrm{T}_{4}$ and total $\mathrm{T}_{3}$ levels were $9.91 \mathrm{ng} / \mathrm{dl}$ and $484 \mathrm{ng} / \mathrm{dl}$, respectively. The serum TSH level was undetectably low on October 13 while taking $50 \mu \mathrm{g} /$ day $1-\mathrm{T}_{4}$. The titers of autoantibodies against thyroglobulin (TGHA) and microsomes (MCHA) were $\times 200$ and $\times 3,200$, respectively. Seven days following discontinuation of the $1-\mathrm{T}_{4}$ therapy on October 20, she still showed signs of overt hyperthyroidism; methimazole treatment was then started. Ultrasonography of the thyroid performed on October 13 revealed diffuse enlargement with normal echogenicity. ${ }^{123}$ I-thyroid uptake 3 hours after oral administration of $3.7 \mathrm{MBq} \mathrm{Na}{ }^{123} \mathrm{I}$ was increased (15.9\%: normal range 5-14\%) with diffuse but slightly uneven distribution of the radionuclide (Fig. 1). After discon-

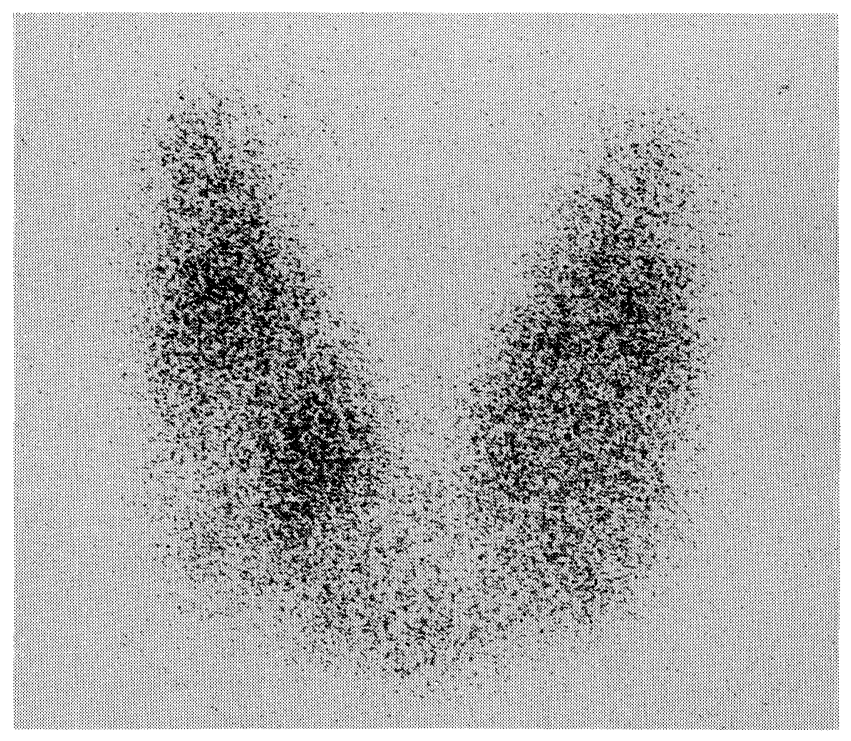

Fig. 1. Scintigraphic appearance of the thyroid gland. Scanning with ${ }^{123} I$ was performed on November 5, 1992. ${ }^{123}$ I-thyroid uptake three hours after oral administration of $3.7 \mathrm{MBq} \mathrm{Na}{ }^{123} \mathrm{I}$ was $15.9 \%$ (the normal range, 5-14\%). tinuation of methimazole treatment on October 30, methimazole was started again on November 21 because of hyperthyroidism. She remained euthyroid both clinically and biochemically under methimazole treatment from August 13, 1993 until the latest follow-up date (March 1994).

As shown in Table 1, TBII and TSAb activities were positive at $18.3 \%$ and $2.8 \mu \mathrm{U} / \mathrm{ml}$ bTSH eq, respectively, in the hypothyroid state when she was first seen at our hospital in August 1992. When she became hyperthyroid in October 1992, TBII became undetectable. Since then TBII has been negative. TSAb and TSBAb activities have remained positive and negative, respectively, throughout the observation period.

\section{Discussion}

The thyrotoxicosis observed in the present patient can be explained by hyperthyroidism due to Graves' disease because of the detection of TSAb in her serum and the increased ${ }^{123} \mathrm{I}$ thyroidal uptake. Three factors are considered to be responsible for the change in her thyroid function from hypothyroidism to hyperthyroidism: 1) disappearance or decrease in titer of a blocking-type TRAb (2-4, 6-8), 2) emergence or increase in titer of stimulating-type $\operatorname{TRAb}(1-5,7,8)$, and 3$)$ recovery from transient hypothyroidism concomitant with hyperthyroidism (16).

The present assay for TSBAb yields underestimation of the activity in serum samples with positive TSAb, since the production of cAMP in the presence of TSAb-positive IgG and TSH is greater than that in the presence of control IgG and TSH. This could raise the possibility that her hypothyroidism might have been due to the inhibitory effect of blocking TRAb on the thyroid function. According to Konishi et al (17), TSBAb activities are detected in hypothyroid patients with weakly positive or even in those with negative TBII. Detection of TBII only in the hypothyroid state might suggest the blocking nature of the antibody. However, it is unlikely that the present patient had a blocking TRAb and showed false-negative activity of TSBAb, in view of the cAMP responses to $100 \mu \mathrm{U} / \mathrm{ml} \mathrm{bTSH}$

Table 1. Thyroid Function Tests, TSH Receptor Antibodies and Treatment Regimen during the Observation Period

\begin{tabular}{|c|c|c|c|c|c|c|c|c|c|}
\hline & $\begin{array}{c}\mathrm{FT}_{4} \\
(\mathrm{ng} / \mathrm{dl})\end{array}$ & $\begin{array}{c}\mathrm{T}_{3} \\
(\mathrm{ng} / \mathrm{dl})\end{array}$ & $\begin{array}{c}\text { TSH } \\
(\mu \mathrm{U} / \mathrm{ml})\end{array}$ & TGHA & MCHA & $\begin{array}{l}\text { TBII } \\
(\%)\end{array}$ & $\begin{array}{c}\text { TSAb } \\
(\mu \mathrm{U} / \mathrm{ml} \text { bTSH eq })\end{array}$ & $\begin{array}{c}\text { TSBAb } \\
(\%)\end{array}$ & Treatment \\
\hline 24 Aug. 1992 & 0.46 & 102 & 19.6 & N.D. & N.D. & 18.3 & 2.8 & -18.9 & - \\
\hline 13 Oct. 1992 & 9.91 & 484 & $<0.05$ & $\times 200$ & $\times 3,200$ & N.D. & N.D. & N.D. & $1-T_{4} 50 \mu \mathrm{g} / \mathrm{D}$ \\
\hline 27 Oct. 1992 & 3.42 & 214 & $<0.05$ & $<\times 100$ & $\times 3,200$ & 9.3 & 0.4 & -10.4 & MMI $15 \mathrm{mg} / \mathrm{D}$ \\
\hline 16 Nov. 1992 & 3.59 & 171 & $<0.05$ & $\times 100$ & $\times 3,200$ & 11.3 & 2.0 & -1.1 & - \\
\hline 7 Dec. 1992 & 3.20 & 189 & $<0.05$ & $<\times 100$ & $\times 6,400$ & 9.1 & 5.0 & -15.5 & MMI 15mg/D \\
\hline 28 Dec. 1992 & 2.03 & 143 & $<0.05$ & $<\times 100$ & $\times 3,200$ & N.D. & 1.0 & -13.3 & MMI 15mg/D \\
\hline 17 Aug. 1993 & 0.74 & 129 & 4.47 & $\times 200$ & $\times 1,600$ & 2.9 & 0.5 & N.D. & MMI 15mg/D \\
\hline 7 De. 1993 & 0.90 & 126 & 3.29 & N.D. & N.D. & 5.7 & N.D. & N.D. & MMI 5mg/D \\
\hline 1 Mar. 1994 & 0.91 & 118 & 2.70 & N.D. & N.D. & 0.0 & N.D. & N.D. & MMI 5mg/D \\
\hline Normal range & $0.8 \sim 1.8$ & $93 \sim 181$ & $0.34 \sim 3.5$ & $<100$ & $<100$ & $<15$ & $<0.3$ & $-29 \sim+21$ & \\
\hline
\end{tabular}

Duration of $1-\mathrm{T}_{4}$ treatment: from September 21 to October 13. Duration of MMI treatment: from October 20 to October 30, and from November 21 to the latest follow-up date. N.D.: not determined, D: day. 
employed for the TSBAb assay (43-fold increase) and to the patient's IgG in the TSAb assay (9.2-fold increase) and the assay result from TSBAb measurement $(-18.9 \%$ in Table 1$)$.

Diffuse but slightly patchy uptake of ${ }^{123}$ I suggests that the present patient had concomitant Hashimoto's thyroiditis. Therefore, it is conceivable that thyroid follicular cells with severe autoimmune destruction might have caused hypothyroidism in spite of the presence of TSAb, and that the balance between the stimulatory effect of TSAb and the thyroid destruction was altered to cause subsequent hyperthyroidism. However, there was no increase in TSAb activity in concurrence with the development of hyperthyroidism, unlike most patients with the early stage of Graves' disease (10). TSAb in her serum fluctuated but was continuously positive throughout the whole course. The slight decrease in TSAb on October 27, 1992 might have been reflective of the natural course of the disease $(18,19)$ and/ or the secondary suppression of TSH after $\mathrm{T}_{4}$ administration (19-21).

With respect to the third factor responsible for the change of her thyroid function, transient hypothyroidism induced by an iodide overintake has been reported in a TSAb-positive patient with subclinical hyperthyroidism (22). However, the present patient did not take excessive iodine.

Shigemasa et al (16) recently reported a case of transient hypothyroidism following subacute aggravation of chronic thyroiditis during antithyroid drug therapy for Graves' hyperthyroidism. Although the past history revealed that the present patient had not presented thyrotoxic symptoms, we would speculate that she was in the hypothyroid state at her first visit following destructive thyroiditis. It is uncertain whether the development of hypothyroidism was preceded by the detection of TSAb or not. In this regard, Morita et al (23) and Tamai et al (24) reported that TSAb and TBII are detected in some patients with silent thyroiditis and subacute thyroiditis, respectively, suggesting that the tissue damage due to destructive thyroiditis causes a release of antigen and a corresponding increase in TBII and TSAb activities.

There may be other unknown factors involved in the mechanism of impaired responses of thyroid follicular cells to TSAb at the hypothyroid phase. The possibility that the abnormal response of the $\mathrm{PIP}_{2}$ cascade, an alternative index of thyroid stimulation for TSH and TRAb, was somehow changed could also be considered.

Although the detection of TSAb in autoimmune hypothyroidism has been reported to be uncommon $(1,4-7,22,18-20$, 25-31), it is important to keep in mind that hypothyroid patients with positive TSAb may quickly develop Graves' hyperthyroidism as discussed in previous reports $(1,4-7,22)$ and in the present paper.

Acknowledgements: The authors wish to thank Dr. K. Kasagi for the review of this manuscript, Dr. H. Yano for valuable comments and Miss M. Nakatsukasa for her helpful assistance.

\section{References}

1) Kasagi K, Konishi J, Iida Y, Mori T, Torizuka K. Changes in thyroid- stimulating and TSH binding inhibitory activities in a patient who developed hyperthyroidism due to Graves' disease following primary hypothyroidism. Clin Endocrinol 25: 519, 1986.

2) Takeda K, Takamatsu J, Kasagi K, et al. Development of hyperthyroidism following primary hypothyroidism: a case report with changes in thyroidrelated autoantibodies. Clin Endocrinol 28: 341, 1988.

3) Cho BY, Shong YK, Lee HK, Koh CS, Min HK. Graves' hyperthyroidism following primary hypothyroidism: sequential changes in various activities of thyrotropin receptor antibodies following primary hypothyroidism. Acta Endocrinol 120: 447, 1989.

4) Takasu N, Yamada T, Sato A, et al. Graves' disease following hypothyroidism due to Hashimoto's disease: Studies of eight cases. Clin Endocrinol 33: $687,1990$.

5) Tamai H, Kasagi K, Mizuno O, et al. Thyroid-stimulating antibody and thyrotropin-binding inhibitory immunoglobulin activity in hypothyroid patients who subsequently developed thyrotoxicosis. Acta Endocrinol 122: 499, 1990.

6) Kraiem Z, Baron E, Kahana L, Sadeh O, Sheinfeld M. Changes in stimulatin $\mathrm{g}$ and blocking TSH receptor antibodies in a patient undergoing three cycles of transition from hypo to hyper-thyroidism and back to hypothyroidism. Clin Endocrinol 36: 211, 1992.

7) Kasagi K, Hidaka A, Endo K, et al. Fluctuating thyroid function depending on the balance between stimulating and blocking types of TSH receptor antibodies: a case report. Thyroid 3: 315, 1993.

8) Miyauchi A, Amino N, Tamaki H, Kuma H. Coexistence of thyroidstimulating and thyroid-blocking antibodies in a patient with Graves' disease who had transient hypothyroidism. Am J Med 85: 418, 1988.

9) Tamaki H, Amino N, Aozasa M, Mori M, Tanizawa O, Miyai K. Serial changes in thyroid-stimulating antibody and thyrotropin binding inhibitor immunoglobulins at the time of postpartum occurrence of thyrotoxicosis in Graves' disease. J Clin Endocrinol Metab 65: 324, 1987.

10) Kasagi K, Tamai H, Morita $T$, et al. Role of thyrotropin receptor antibodies in the development of hyperthyroidism: follow-up studies on nine patients with Graves' disease. J Clin Endocrinol Metab 68: 1189, 1989.

11) Tamai H, Kasagi K, Morita T, et al. Thyroid response, especially to thyrotropin-binding inhibitory immunoglobulins, in euthyroid relatives of patients with Graves' disease: a clinical follow-up. J Clin Endocrinol Metab 71: 210, 1990.

12) Shewring G, Smith BR. An improved radioreceptor assay for TSH receptor antibodies. Clin Endocrinol 17: 409, 1982.

13) Amino N, Watanabe H, Tamaki H, Iwatani $Y$, Miyai K. In-vitro conversion of blocking type anti-TSH receptor antibody to the stimulating type by anti-human IgG antibodies. Clin Endocrinol 27: 615, 1987.

14) Watanabe $Y$, Yonezawa M, Hikuchi K, et al. Measurement of thyroid stimulating antibodies and TSH stimulating inhibitor antibodies using cultured porcine thyroid cells. Clin Endocrinol 105: 637, 1987 (Japanese).

15) Kasagi K, Konshi J, Arai K, et al. A sensitive and practical assay for thyroid-stimulating antibodies using crude immunoglobulin fractions precipitated with polyethylene glycol. J Clin Endocrinol Metab 62: 855, 1986.

16) Shigemasa $C$, Shirota $K$, Urabe $K$, et al. Onset of subacute aggravation of chronic thyroiditis followed immediately by transient hypothyroidism during antithyroid drug therapy for Graves' hyperthyroidism. Horm Res 35: 208,1991

17) Konishi J, Iida Y, Endo K, et al. Inhibition of thyrotropin-induced adenosine 3',5'-monophosphate increase by immunoglobulins from patients with primary myxedema. J Clin Endocrinol Metab 57: 544, 1983.

18) Sato K, Okumura K, Yoshinari M, et al. Goitrous hypothyroidism with blocking or stimulating thyrotropin binding inhibitor immunoglobulins. J Clin Endocrinol Metab 71: 855, 1990.

19) Tamaki H, Amino N, Iwatani Y, Miyai K. Improvement of infiltrative ophthalmopathy in parallel with decrease of thyroid-stimulating antibody (TSAb) activity in two patients with hypothyroid Graves' disease. J Endocrinol Invest 12: 47, 1989.

20) Tamai H, Kasagi K, Hara T, et al. Follow-up study of thyroid stimulating- 


\section{YAMASAKI et al}

blocking antibodies in hypothyroid patients. Clin Endocrinol 33: 699, 1990.

21) Hashizume K, Ichikawa K, Sakurai A, et al. Administration of thyroxine in treated Graves' disease. Effects on the level of antibodies to thyroidstimulating hormone receptors and on the risk of recurrence of hyperthyroidism. N Engl J Med 324: 947, 1991.

22) Kasagi K, Hidaka A, Nakamura H, et al. Thyrotropin receptor antibodies in hypothyroid Graves' disease. J Clin Endocrinol Metab 76: 504, 1993.

23) Morita $\mathrm{T}$, Tamai $\mathrm{H}$, Oshima $\mathrm{A}$, et al. The occurrence of thyrotropin binding-inhibiting immunoglobulins and thyroid-stimulating antibodies in patients with silent thyroiditis. J Clin Endocrinol Metab 71: 1051, 1990.

24) Tamai H, Nozaki T, Mukuta T, et al. The incidence of thyroid stimulating blocking antibodies during the hypothyroid phase in patients with subacute thyroiditis. J Clin Endocrinol Metab 73: 245, 1991.

25) Tamai H, Kasagi K, Takaichi Y, et al. Development of spontaneous hypothyroidism in patients with Graves' disease treated with antithyroidal drugs: clinical, immunological, and histological findings in 26 patients. J Clin Endocrinol Metab 69: 49, 1989.
26) Zakarija M, McKenzie JM, Banovac K. Clinical significance of assay of thyroid-stimulating antibody in Graves' disease. Ann Intern Med 93: 28, 1990.

27) Vitti P, Rotella CM, Valente WA, et al. Characterization of the optimal stimulatory effects of Graves' monoclonal and serum immunoglobulin $\mathrm{G}$ on adenosine 3',5'-monophosphate production in FRTL-5 thyroid cells: a potential clinical assay. J Clin Endocrinol Metab 57: 782, 1983.

28) Rapoport B, Greenspan FS, Filetti S, Pepitone M. Clinical experience with a human thyroid cell bioassay for thyroid-stimulating immunoglobulin. J Clin Endocrinol Metab 58: 332, 1984.

29) Grant SJB, Luttrell BM, Hales IB. The assay for thyroid stimulating immunoglobulins using cultured human thyroid cells. Clin Endocrinol 23: 325, 1985.

30) Smith BR, McLachlan SM, Furmaniak J. Autoantibodies to the thyrotropin receptor. Endocr Rev 9: 106, 1988.

31) Kasagi K, Takeda K, Goshi K, et al. Presence of both stimulating and blocking types of TSH-receptor antibodies in sera from three patients with primary hypothyroidism. Clin Endocrinol 32: 253, 1990. 